\title{
Association between Psychosocial Factor and Risk of Musculosceletal Disorders in Productive Age Patient at RSUD Dr. Moewardi Surakarta
}

\author{
Dea Linia Romadhoni ${ }^{*}$, Alinda Nur Ramadhani ${ }^{2}$ \\ ${ }^{1}$ Universitas 'Aisyiyah Surakarta \\ ${ }^{2}$ Universitas 'Aisyiyah Surakarta \\ *E-mail: Dealiniafisio@gmail.com
}

https://doi.org/10.30787/gaster.v19i1.661

\begin{tabular}{|c|c|}
\hline ARTICLE INFO & ABSTRACT \\
\hline $\begin{array}{l}\text { Keywords: Musculoskeletal } \\
\text { Disorders (MSDs); Psycho- } \\
\text { logical Factors; Social Factor }\end{array}$ & $\begin{array}{l}\text { Musculoskeletal Disorders (MSDs) is a form of complaint } \\
\text { that occurs in bones, joints, ligaments, tendons, and muscles. } \\
\text { Globally, MSDs are the biggest single cause of health } \\
\text { complaints among workers. The purpose of this study was to } \\
\text { analyze psychosocial factors that can increase risk of MSDs } \\
\text { in reproductive age patients. This study used an analytic } \\
\text { observational study with cross-sectional design. A sample 0f } 116 \\
\text { subject was selected for this study by fixed disease sampling. } \\
\text { Data were collected by questionnaire and medical record, and } \\
\text { analyzed by path analysis. Results: Risk of MSDs was directly } \\
\text { related to with non-ergonomic work posture (OR: 2.35; CI } \\
\text { 95\%:1.44 to 3.26; P<0.001), there was indirect association with } \\
\text { stress level variable (OR:0.79;CI 95\%:0.01 to 1.58;P=0.047) } \\
\text { which affected by type of work variabel (OR:0.83;CI 95\%:0.87 } \\
\text { to 1.58;P=0.029) and indirectly assaciated with bad work } \\
\text { environment (OR:1.07; CI 95\%:0.28 to 1.85;P=0.008) }\end{array}$ \\
\hline
\end{tabular}

Musculoskeletal disorders (MSDs) are a complaint when muscles receive a static load repeatedly over long period of time, it will cause complaints in the form of damage to joints, ligaments and tendon (Dwiseli et al., 2019). Musculoskeletal disorders (MSDs) are the leading cause of absence at work in the United States with the most common musculoskeletal injuries are sprains and strains. A similar problem also occurs in workers in Brazil, with MSDs being the most common complaints on the shoulder (49\%), neck (47\%) and spine (39\%) (Kim, 2017). 
Study in Arab Saudi found that at least $13 \%$ workers take time off due to MSDs, $22 \%$ have to reduce their work-related hours and $46 \%$ have to undergo regular medical treatment due to MSDs (Iqbal and Alghadir, 2015). Study in Hongkong found that in 2016, $39,2 \%$ of workers suffer from musculoskeletal pain (Yi and Chan, 2016).

Study from Prasetya et al, (2017) showed that $62,5 \%$ of workers complained of high musculoskeletal disorders. Result from a preliminary study conducted on outpatients at the Dr. Moewardi Hospital Surakarta showed that in 2017 there were 650 patients or more than $40 \%$ of cases in physiotherapy clinic complaining of MSDs.

MSDs can affect decreasing of productivity and cause an increasing of economic burden on a company due to the expenditure of additional funds for health compensation an insurance for workers.

Psychosocial factors that can increase the risk of MSDs are work posture, work environment, type of work, and stress level (Romadhoni, 2018).

Work-related stress may result in decreased concentration and ability to make decisions so that workers become confused, forgetful and doubtful which can affect accidents and injuries so that it is easy for workers to experience the risk of MSDs (Sharma and Singh, 2015). Stress levels can affect pain rather than physiological responses associated with pain and also affect pain in certain parts when the psychological condition is bad (Bergsten et al., 2015).

Stress levels can be measured using the perceived stress scale (PSS), PSS assesses external demands that play a role beyond the ability of an individual so that an individual is unable to overcome it (Nielsen et al., 2016).

PSS originally consisted of 14 items scale and developed into 10 items and is often used to measure stress level due to external factors (Khalili et al., 2017).

Psychosocial factors that increase the risk of MSDs include the heavier work, the higher level of pain that is felt, makes the person more at risk of developing MSDs (Bergsten et al, 2015). Type of work affects how high the risk of MSDs. Workers with excessive physical activity $76,2 \%$ at risk of MSDs (Yi and Chan, 2016). Work identifies an activity that on average takes a lot of time in each day so that it is physically demanding to work excessively which has an impact and impacts on the risk of MSDs (Blackwell and Clarke, 2016). 
Work environment is defined as everything that is in the workplace or state of workplace, such as ventilation system, room temperature, dust, humidity, workspace lighting (lighting intensity), noise level and workplace design (Joseph, 2016). Nonergonomic work environmental may increase risk of MSDs by $20 \%$, other research suggest that poor work environment increase $34,4 \%$ risk of MSDs (Prasetya et al, 2017).

Work environment can be assessed using the PLIBEL checklist that was designed by Dr. Kemmlert in 1995. PLIBEL checklist have been widely used in measuring work environment related to ergonomic risk on five limbs: neck, shoulder, upper back, elbows, forearm and hand then added with knees, hips, and low back (Kusmasari et al., 2018).

Work posture is the position of the body during the performance of work. Work posture has a very significant impact on the efficiency and performance of workers so that it affects health problem of workers. Work posture is divided into three type, easy posture, fatigue posture and rigid posture (Rahmayati and Kasmini, 2020), non-ergonomic work posture in a fixed body position for several hours can increase risk of MSDs by 62,8\% (Chinyere, 2014).
This study aimed to examine association between psychosocial factors and risk of MSDs in terms of the direct and indirect association of the independent variable to the dependent variable.

\section{METHODS AND MATERIALS}

This study used an analytic observational study with cross-sectional approach. The target population in this study were outpatient with MSDs in the medical rehab clinic of Dr. Moewardi Surakarta hospital in 2017/2018. Subject of this study were outpatients of Physiotherapy clinic Dr. Moewardi Hospital Surakarta with a diagnosis of MSDs. This study used fixed disease sampling, number of samples was taken based on the representation of 15 samples on the independent variables in order to obtain 116 samples.

The inclusion criteria are patients who work as workers/employee, work time $\geq 8$ hours, willing to be respondents for the study and at productive age (30-60 years). The exclusion criteria included patients who had a history of fractures, had spinal abnormalities and had a history of smoking. Type of work is a form of activity carried out by research subjects to earn income, such as factory workers, employees, police, and teacher. 
The work environment was analyzed using the PLIBEL checklist. Work posture was measured by rapid entire body assessment (REBA) method. The stress level was assessed using PSS. MSDs data were taken based on the medical record.

Bivariate analysis aims to analyze the association of two variables using chi-square test and calculating the odds ratio (OR) with a confidence level (CI) of 95\%. Multivariate analysis was done using path analysis to determine direct and indirect associations.

\section{RESULT AND DISCUSSION}

Characteristic description of the respondents based on primary and secondary data is described in table 1 . Subjects that tend to have more moderate type of work $(56.9 \%)$ than the heavy type of work (43.1\%), subjects who had severe stress level (52.6\%). More than $50 \%$ of the subject's work environment is in the high-risk category of MSDs with a high work posture as much as $45.7 \%$ and very high as much as $8,6 \%$. Subjects with acute MSDs (57.8\%) were higher than those with chronic MSDs (42.2\%).

Table 1. Characteristics of the Subjects

\begin{tabular}{llcl}
\hline \multicolumn{1}{c}{ Characteristics } & \multicolumn{1}{c}{ Criteria } & Frequency & $(\mathbf{\%})$ \\
\hline Type of work & Heavy work type & 66 & 56,9 \\
& Hard work type & 50 & 43,1 \\
Work Environment & $<43 \%$ & 56 & 48,3 \\
& $>43 \%$ & 60 & 51,7 \\
Work Posture & $\leq 4$ & 53 & 45,7 \\
\multirow{3}{*}{ MSDs } & $\geq 4$ & 63 & 54,3 \\
& Acute & 67 & 57,8 \\
& Chronic & 49 & 42,2 \\
\hline
\end{tabular}

The results were analyzed using STATA 13 with 5 variables, 3 endogenous variables and 1 exogenous variable, so that the degree of freedom (df) value is 10 where path analysis can be carried out. The results of the path analysis are described in Figure 1 below: 
Gambar 1. Structural Model of Path Analysis with Estimation

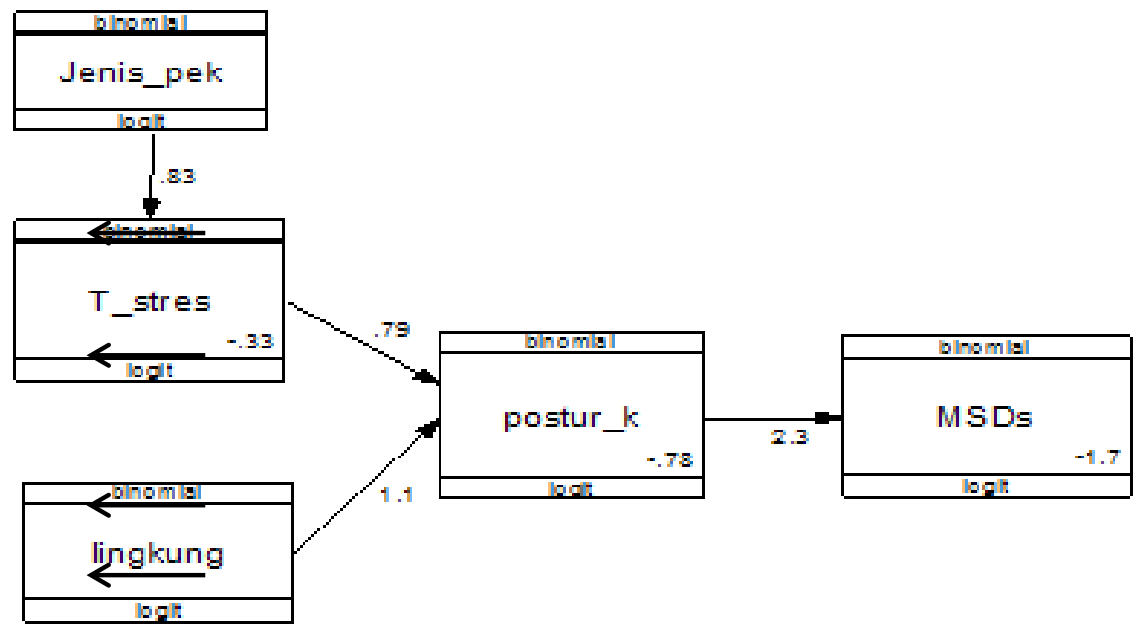

Table 2. The Results of Path Analysis Association of Psychosocial Factors of MSDs

\begin{tabular}{|c|c|c|c|c|c|}
\hline & \multirow[t]{2}{*}{ Variable } & \multirow{2}{*}{$\begin{array}{c}\text { Independent } \\
\text { Variable }\end{array}$} & \multicolumn{2}{|c|}{ CI $(95 \%)$} & \multirow[t]{2}{*}{$\mathrm{P}$} \\
\hline & & & $\begin{array}{l}\text { Upper } \\
\text { Limit }\end{array}$ & $\begin{array}{l}\text { Lower } \\
\text { Limit }\end{array}$ & \\
\hline \multicolumn{6}{|l|}{ Direct Effect } \\
\hline MSDs & Work Posture & 2.35 & 1.44 & 3.26 & $<0.001$ \\
\hline \multicolumn{6}{|l|}{ Indirect Effect } \\
\hline Work Posture & $\begin{array}{l}\text { Work } \\
\text { Environment }\end{array}$ & 1.07 & 0.28 & 1.85 & 0.008 \\
\hline Work Posture & Stress Level & 0.79 & 0.01 & 1.58 & 0.047 \\
\hline Stress Level & Type of work & 0.83 & 0.87 & 1.58 & 0.029 \\
\hline Log likelihood & -214.049 & & & & \\
\hline
\end{tabular}

Table 2 showed a direct positive association between non-ergonomic work posture on MSDs and is shown to be statistically significant (OR: 2.35; CI 95\%: 1.44 to $3.26 ; \mathrm{P}<0.001)$.

This finding was in accord with a previous study which explained that an ergonomic work posture will increase the risk of MSDs such as factory workers lifting large quantities of goods simultaneously and involves excessive movement of work such as turning right and left or bend more than 60 degrees. This causes an increase in the risk of MSDs in factory workers, especially in the 
upper extremities such as CTS, torticollis, and in lower extremities such as LBP and OA (Romadhoni, 2018).

Ansari and Sheikh, (2014) research on handicraft workers where there are about $53 \%$ of workers with high level of risk. Based on their study, if workers continue to work in the same posture then they may have the risk of MSDs in the neck, shoulders and wrists in the near future, this is due the twisting of the arm and bending over while working.

Previous studies that are in line with this result are research conducted on restaurant workers. This study explained that some servants will carry multiple items using one hand, others open the door, while others will share same weight on both hands. The result showed that $59 \%$ cases of musculoskeletal disorders in female servants and $40 \%$ in male worker (Laperrière et al., 2017).

The type of work is very influential on the risk of MSDs because they require continuous strength and repetition while working and lack of rest period so that the limbs are very vulnerable to MSDs (Hembecker et al., 2017).

The risk of MSDs does not only affect heavy-duty workers, but even moderate type of work may at risk of MSDs due to discomfort when doing work, both psychologically and mental and work posture (Laal et al., 2017)

Table 2 also explained that there was indirect positive association and statistically significant with the high stress level variable (OR: 0.79; CI 95\%: 0.01 to $1.58 ; \mathrm{P}=0.047$ ). Stress level are associated with MSDs risk through work posture. Subjects with high stress level are more likely to develop MSDs. This occurs as a result of the tension in the back muscles which can affect their posture when working, who have high stress level tend to bend over and looking down so that they form a non-ergonomic work posture. Subjects who have high stress levels tend to develop LBP and myalgia.

Study conducted by Charles et al., (2017) stated that work closely related to job demands, low social support, low work control and monotonous work. This can affect stress level of workers so that many workers complain of pain in the neck and shoulders, this complaint is also associated with poor work posture such as non-ergonomic work postures that cause the neck to flex for too long with repetitive movements so that it will be very vulnerable to the risk of MSDs.

The results of table 2 showed an indirect association with a bad work environment (OR: 1.07; CI 95\%: 0.28 to $1.85 ; \mathrm{P}=0.008)$. Work environment associated with risk of MSDs 
through work postures. Non-ergonomic work environment may increase the risk of MSDs. The subject will adjust their work posture with the work environment. For example, employees with a narrow work space and uncomfortable chairs will form a nonergonomic work posture, because the narrow work space makes the subject experience limitation in movement so that it will form a dynamic work posture throughout working hours.

This finding was in accord with the result from previous study in medical profession, especially dentist. There was a significant result where dentists tended to have higher cervical MSDs complaints than other areas, which was due to the fact that dentists had to flex their neck and sit for hours while doing treatment on their patients (Taylor et al, 2018).

Study from Park et al., (2017) on manufacturing workers showed that $38 \%$ of workers were at risk of MSDs due to bad work posture caused by a bad work environment. In this study, respondents were asked to do work with heavy loads and carried out repeatedly with a work posture that was not in accordance with the work equipment.

Table 2 showed a direct positive association between the type of work and level of stress (OR: 0.83; CI 95\%: 0.87 to 1.58; $\mathrm{P}=0.029)$. Result from Amin et al., (2018) study showed that worker stress level of $51,6 \%$ was significant with the risk of MSDs. This caused due to high work demands that affect the psychological responses that can increase pain and musculoskeletal disability of the musculoskeletal system.

Previous study suggested that occupational groups including community workers, office workers, specialized health workers, and mining workers, may indicate multifactorial MSDs, one of these factors is stress level (Fulmer et al., 2017).

\section{CONCLUSSION AND SUGGESTION}

Based on the result of path analysis of the relationshionship between psychosocial factor an the risk of MSDS, there was direct association between non-ergonomic work posture with an increased risk of MSDs and there was indirect association between stress level, work environment and type of work with an increased risk of MSDs.

This study is expected to be developed by anlyzing MSDs using a case control approach to spesifically examine factors that realated to MSDs and analyzed other factors that have not been studied in this study. 


\section{REFERENCES}

Amin, N. A. Quek, K.F., Oxley, J.A., Noah, R., and Nordin, R. (2018). 'Emotional distress as a predictor of workrelated musculoskeletal disorders in Malaysian nursing professionals', International Journal of Occupational and Environmental Medicine, 9(2), pp. 69-78. doi: 10.15171/ijoem.2018.1158.

Ansari, N. A. and Sheikh, M. J. (2014). 'Evaluation of work Posture by RULA and REBA : A Case Study', 11(4), pp. $18-23$.

Bergsten, E. L., Mathiassen, S. E. and Vingård, E. (2015). 'Psychosocial work factors and musculoskeletal pain: A cross-sectional study among swedish flight baggage handlers', BioMed Research International. doi: $10.1155 / 2015 / 798042$.

Blackwell, D. L. and Clarke, T. C. (2016). 'Occupational differences among employed adults who met 2008 federal guidelines for both aerobic and musclestrengthening activities: United States, 2008-2014', National Health Statistics Reports, 2016(94).

Charles L. E., Ma, C. C., Burchfiel, C. M., and Dong, R. G (2017). 'Vibration and Ergonomic Exposures Associated With Musculoskeletal Disorders of the Shoulder and Neck', Safety and Health at Work. doi: 10.1016/j. shaw.2017.10.003.

Chinyere N, I. (2014). 'Influence of Workstation and Work Posture Ergonomics on Job Satisfaction of Librarians in the Federal and State University Libraries in Southern Nigeria', IOSR Journal of Humanities and Social Science, 19(9), pp. 78-84. doi: 10.9790/0837-19947884.

Dwiseli, F., Rahim, M. R. and Awaluddin (2019). 'Factors associated with musculoskeletal disorders (MSDs) complaint on the workers of cargo unit at PT. Angkasa Pura Logistics, Makassar in 2017', Indian Journal of Public Health Research and Development, 10(7), pp. 1040-1044. doi: 10.5958/0976-5506.2019.01717.0.

Fulmer S., Buchholz B., Scribani M., and Jenkins P. (2017). 'Musculoskeletal Disorders in Northeast Lobstermen', Safety and Health at Work, 8(3), pp.282289. doi: 10.1016/j.shaw.2016.12.004.

Hembecker P. K., Reis D.C., Konrath A.C., Gontijo L.A., and Merino E.A.D. (2017). 
'Investigation of musculoskeletal symptoms in a manufacturing company in Brazil: a cross-sectional study', Brazilian Journal of Physical Therapy, 21(3), pp. 175-183. doi: 10.1016/j. bjpt.2017.03.014.

Iqbal, Z. and Alghadir, A. (2015). 'Prevalence of work-related musculoskeletal disorders among physical therapists.', Medycyna Pracy, 66(4), pp. 459-469. doi: 10.13075/mp.5893.00142.

Joseph, I. (2016). 'Analysis the Influence of Physical Work Environment and Non-Physical Work Environment on Employee Productivity in General Hospital Gmim Kalooran Amurang South Minahasa Regency', Jurnal Berkala Ilmiah Efisiensi, 16(4), pp. 407-420.

Khalili R., Masoud S., Abbas E., Tavallai A., and Habibi M .(2017). 'Validity and reliability of the Cohen 10-item Perceived Stress Scale in patients with chronic headache: Persian version', Asian Journal of Psychiatry, 26, pp. 136-140. doi: 10.1016/j. ajp.2017.01.010.

Kim, I. J. (2017) .'The Role of Ergonomics for Construction Industry Safety and Health Improvements', Journal of Ergonomics, 7(2), pp. 2-5. doi: 10.4172/2165-7556.1000e166.

Kusmasari, W., . Y. and Sutalaksana, I. Z. (2018). 'Risk Factors for Musculoskeletal Symptoms of Construction Workers: A Systematic Literature Review', KnE Life Sciences, 4(5), p. 1. doi: 10.18502/kls.v4i5.2535.

Laal F., Madvari R.F., Balarak D., Mohammadi M., Dortaj E., Khammar A., and Adineh H.A. (2017). 'Association between musculoskeletal disorders and anthropometric indices among bus drivers in Zahedan city', International Journal of Occupational Safety and Ergonomics, 0(0), pp. 1-7. doi: 10.1080/10803548.2017.1334335.

Laperrière, È., Messing, K. and Bourbonnais, R. (2017). 'Work activity in food service: The significance of customer relations, tipping practices and gender for preventing musculoskeletal disorders', Applied Ergonomics, 58, pp. 89-101. doi: 10.1016/j.apergo.2016.05.013.

Nielsen, M. G., Ørnbøl E., Vestergaard M., Bech P., Larsen F.B., Lasgaard M., and Christensen K.S. (2016). 'The construct validity of the Perceived Stress Scale', 
Journal of Psychosomatic Research, 84, pp. 22-30. doi: 10.1016/j. jpsychores.2016.03.009.

Park, J., Kim, Y. and Han, B. (2017). 'Work Sectors with High Risk for WorkRelated Musculoskeletal Disorders in Korean Men and Women', Safety and Health at Work, pp. 4-7. doi: 10.1016/j. shaw.2017.06.005.

Prasetya, T., Rosanti, E. and Rahma, R. (2017). 'Analysis of Factors Causing Musculoskeletal Disorders using Rula ( Rapid Upper Limb Assessment ) Method in Computer Operators', International Journal of Applied Environmental Sciences, 12(2), pp. 323-340.

Rahmayati, D. A. and Kasmini, O. W. (2020). 'Influence Work Station Design and Firm Constitutional Complaint Against Musculoskeletal on Stone Crusher Worker Progo in Magelang', Public Health Perspective Journal, 5(2), pp. 147-154.
Romadhoni, D. (2018). Faktor Biopsikososial yang Dapat Mempengaruhi Risiko MSDs Pada Pasien Rawat Jalan Di RSUD Dr. Moewardi Surakarta. Tesis

Sharma, R. and Singh, R. (2015). 'WorkRelated Musculoskeletal Disorders, Job Stressors and Gender Responses in Foundry Industry Work-Related MusculoskeletalDisorders, JobStressors and Gender Responses in Foundry Industry', 3548(December 2017). doi: 10.1080/10803548.2014.11077053.

Taylor, C. A., Strauss, R. A. and Best, A. M. (2018). 'Postural Preference and Musculoskeletal Complaints in Oral and Maxillofacial Surgeons', Journal of Oral and Maxillofacial Surgery, 76(1), pp. 46-51. doi: 10.1016/j. joms.2017.04.020.

Yi, W. and Chan, A. (2016). 'Health profile of construction workers in Hong Kong', International Journal of Environmental Research and Public Health, 13(12). doi: 10.3390/ijerph13121232. 